\title{
Lessons for REDD+ from Cameroon's past forestry law reform: a political economy analysis
}

\author{
$\underline{\text { Guy Patrice Dkamela }}^{1}, \underline{\text { Maria Brockhaus }}^{2}$, Felicien Kengoum Djiegni $^{2}$, Jolien Schure $^{3}$ and Samuel Assembe Mvondo $^{2}$
}

\begin{abstract}
Reducing emissions from deforestation and forest degradation and enhancing forest carbon stocks (REDD+) is gaining traction in Cameroon. However, given the deep-rooted trans-sectoral drivers of forest loss, enforcing REDD+ policies will require major policy change and reform both within and beyond the forestry sector. In this paper, we view the REDD+ policy arena in Cameroon within a political economy framework and conduct policy network analysis to explore the factors that will enable or hinder efforts to implement the broad policy change required to realize REDD+. As the REDD+ context is shaped by the history of Cameroon's forestry sector, we draw lessons for REDD+ from the forestry law reform undertaken in 1994. We focus our analysis on three factors considered necessary for REDD+ success: (i) autonomy of the nation state from interests behind deforestation and forest degradation, (ii) national ownership over reform processes, and (iii) inclusiveness of policy processes. We find that the REDD+ policy process in Cameroon is repeating the weaknesses of the earlier forestry law reform, as seen in the minimal ownership of REDD+ by national actor groups and low inclusiveness among domestic actors at both national and local levels, as well as the absence of a national coalition for REDD+. Furthermore, politics and private agendas are compromising state agencies' autonomy in making decisions about forest resources. Our findings suggest that responses to these weaknesses, as well as to inconsistencies between sectoral policies and to competition over forest resources, will determine whether REDD+ can induce change within and beyond Cameroon's forestry sector.
\end{abstract}

Key Words: Cameroon; forestry law reform; policy networks; political economy analysis; REDD+ policy process

\section{INTRODUCTION}

Cameroon is in the early stages of a national policy process aimed at establishing policies and measures for reducing emissions from deforestation and forest degradation and enhancing forest carbon stocks, known as REDD+ (Dkamela 2011, UNFCCC 2011, MINEPDED 2013, Somorin et al. 2014). To enforce REDD+ policies, Cameroon will require reforms within and beyond the forestry sector to address cross-sectoral drivers of forest loss (Angelsen 2009, Dkamela 2011). However, the REDD+ policy process is not the first attempt to reform Cameroon's forestry sector: a major reform was initiated in the early 1990s, with a law passed in 1994 setting out regulations on the use and management of forest and wildlife resources (Nguiffo 1994). The implementation of the 1994 forestry law was fraught with difficulties (see Nguiffo 2001, 2004, Cerutti and Tacconi 2006, REM 2009, Topa et al. 2009, Cerutti and Lescuyer 2011) and resulted in a new revision process initiated in 2009 (see Fig. 1). The revision of the 1994 law aimed to address gaps in: forest management; use rights and quantity of locally processed wood; and to introduce provisions for emerging concepts such as payments for ecosystem services and conservation concessions (MINFOF 2012a). Efforts to realize REDD+ must take this context into consideration.

A number of social, political, and economic factors influence the success or failure of larger policy reforms in the forestry sector (see Bates 1981, Grindle and Thomas 1989, 1991, Van de Walle 1989, 2001, Brockhaus and Angelsen 2012, Di Gregorio et al. 2012). For REDD+, Di Gregorio et al. (2012) argue that the following are preconditions for effective policy reform: (i) autonomy of the state from key interests behind deforestation and forest degradation; (ii) national ownership over the reform processes; and (iii) inclusiveness of policy processes, particularly the involvement of sectors beyond forestry and of multilevel state and civil society actors. These factors could explain the poor outcomes of the 1994 forestry law reform, which have often been attributed to weak national ownership, corruption and collusion, and weak horizontal and vertical inclusiveness and coordination between policy actors (Nguiffo 2001, 2004, Cerutti and Tacconi 2006, REM 2009, Cerutti and Lescuyer 2011, Dkamela 2011). It is important to determine whether REDD+ in Cameroon is following a similar trajectory to the 1994 reform and, if so, to develop strategies to avoid similar failings.

In this paper, we aim to draw lessons for REDD+ in Cameroon from the 1994 reform process. We will apply a political economy framework, and analyze the literature and additional data generated through policy network analysis conducted in 2011-2012, to identify obstacles and opportunities that emerged during the 1994 reform process. We will then assess the relevance of these issues for the current REDD+ process. To address these issues we ask the following questions: (i) Which actors are involved in the REDD+ policy process and what was their role in the earlier reform? (ii) How influential is each actor group, i.e., state, civil society, private sector, and international actors, in the policy arena? (iii) What are the main patterns of interactions among actor groups in relation to collaboration and conflict, and which of the coalitions are driving change?

\section{THEORY AND BACKGROUND}

The political economy of deforestation and forest degradation in Cameroon

In recent years, the state of forest resources in Cameroon has been characterized by a slight decline in deforestation, while levels of degradation are increasing. Between 1990 and 2000 Cameroon's estimated annual net deforestation rate was $0.08 \%$ (15,272 ha), and decreased to $0.03 \%$ (5727 ha) between 2000 and 2005 . Conversely, the annual net forest degradation rate was $0.06 \%$ (11,454 ha) between 1990 and 2000 and rose to $0.07 \%$ (13,363 ha) between 2000 and 2005 in the category "dense forest" (Ernst et al. 2012). Deforestation and forest degradation rates in the Congo 
Fig. 1. Key events related to forestry reforms and the REDD+ process in Cameroon.

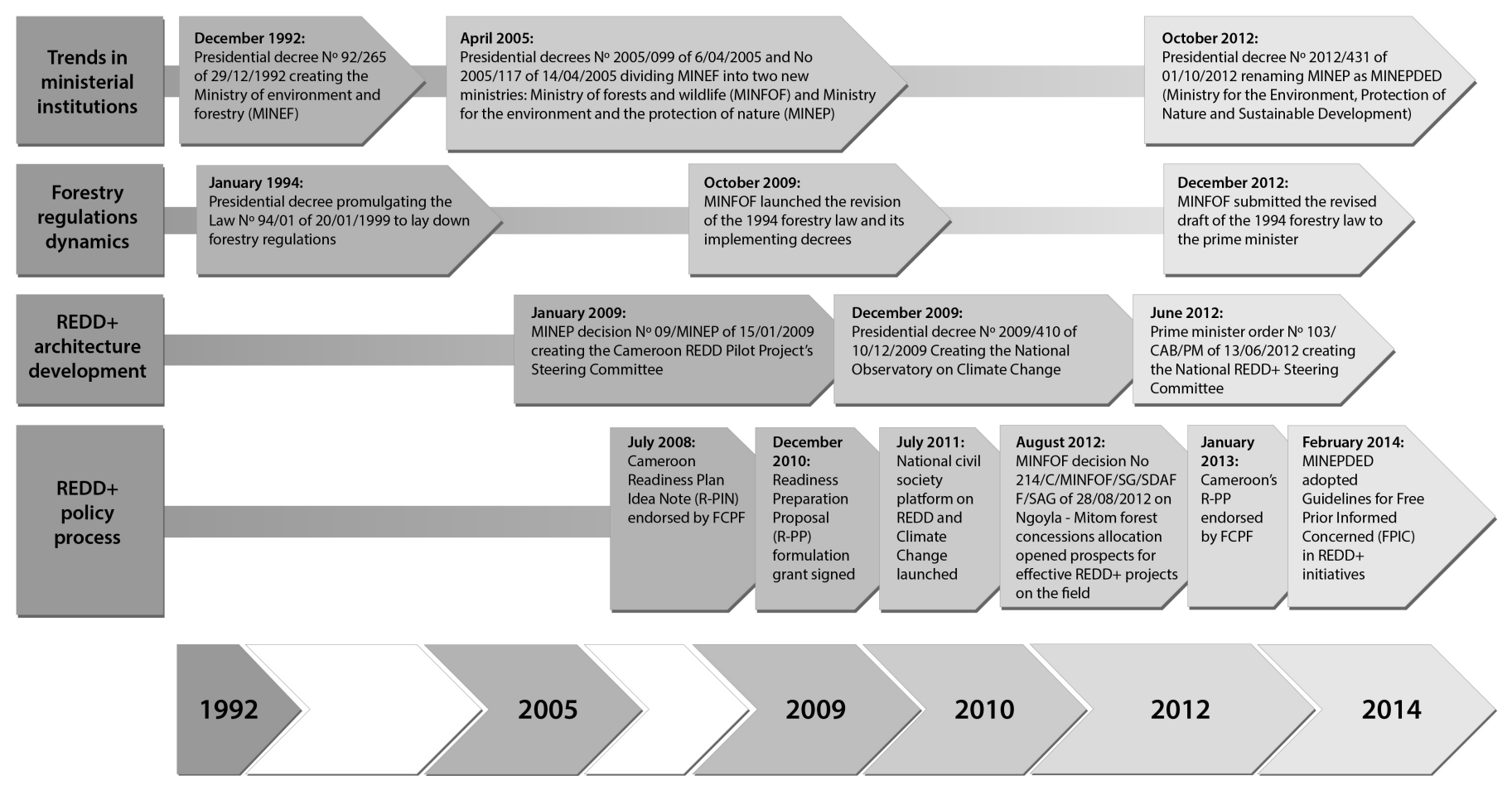

Basin are generally lower than in other regions (Mayaux et al. 2013), and Rudel (2013) argues that state income in the Basin, including tax revenues from oil and mineral industries, could explain these lower deforestation and degradation rates because of increased imports and migration dynamics. Although some scholars argue that "well-controlled" timber exploitation has seemingly little direct influence on forest-cover reduction (Mayaux et al. 2013), it would be necessary, especially from a political economy perspective, to investigate current timber exploitation schemes and the implications for emissions. Forest loss in Cameroon is currently attributed to shifting cultivation, logging, development of monoculture plantations, fuelwood extraction, and macroeconomic policies (see Hédon 1930, Etoga Eily 1971, Essama-Nssah and Gockowski 2000, Mertens and Lambin 2000, Mertens et al. 2000, Ndoye and Kaimowitz 2000, Sunderlin et al. 2000, Brown and Ekoko 2001, Hosonuma et al. 2012). However, new investments in forest areas, such as oil palm plantations, oil and mineral extraction, and infrastructure and energy projects (Dkamela 2011, Greenpeace 2012, Levang and Nkongho 2012, Nguiffo and Schwartz 2012, The Rainforest Foundation UK 2013) will have implications for REDD+ policies because they are likely to increase forest loss.

A political economy lens can enable a deeper understanding of the factors likely to facilitate or hinder attempts to mitigate the main drivers of deforestation and degradation (Brockhaus and Angelsen 2012). Political economy frameworks have been applied in various policy contexts, e.g., reform of macroeconomic and sectoral policies (Grindle and Thomas 1989, 1991); agricultural policies (Bates 1981); and the rice of the subsector (Van de Walle 1989) to understand how interactions among policy actors (i.e., the policy process) shape the policy outputs (i.e., policies and measures) and outcomes (i.e., ultimate impacts). In the context of climate change policies, this type of analysis has led to a wider examination of issues to obtain insights into highly complex and nuanced national circumstances (see Tanner and Allouche 2011, Brockhaus and Angelsen 2012, Di Gregorio et al. 2012). Historically, agricultural and forestry policy making in tropical Africa has been seen by some scholars as "profit seeking" by the urban elite (Bates 1981). However, the rationales that guide policy inputs and outputs are likely to be far more complex than this, involving multiple international, national, and local policy actors and coalitions. Rationales are shaped by these actors' levels of power, interests, and actions, as well as the institutions, ideological drivers, levels of knowledge and capacity that guide them.

In this paper, we apply Brockhaus and Angelsen's (2012) political economy framework, which focuses on the "four Is" relevant to REDD+: institutional stickiness, actors' interests, ideas, and information. Di Gregorio et al. (2012), focus on the first three of these elements to examine national REDD+ processes and identify the following preconditions for transformational change: autonomy, ownership, and inclusiveness. We compare Cameroon's 1994 forestry law reform and the current national REDD+ policy process in light of these preconditions, and adopt the same definition of transformational change as Di Gregorio et al. (2012) and Brockhaus and Angelsen (2012:16-17): "a shift in discourse, attitudes, power relations, and deliberate policy and protest action that leads policy formulation and implementation away from business as usual policy approaches that directly or indirectly support deforestation and forest degradation." 


\section{Autonomy, ownership, and inclusiveness}

Autonomy can be described as the ability of state actors to make decisions with a degree of independence from the sectors driving deforestation and forest degradation, and to withstand lobbying pressure, instead working for the interests of society as a whole (Di Gregorio et al. 2012, Karsenty and Ongolo 2012). We use the presence of collusion and corruption as negative indicators of autonomy, because these have been identified as major obstacles when developing and implementing REDD+ policies (Kanninen et al. 2007). To gain an understanding of how autonomy plays out in the earlier forestry reform and in REDD+, we choose not to consider the diverse issues explaining the dependence of postcolonial states (see Kapoor 2002), but rather to examine how the exercise of public power generates private gain (Kaufmann et al. 2009) and how behavior at the micro level compromises the state's ability to pursue national objectives (Alence 2004).

National ownership of the REDD+ policy process by the government refers to the level of control that state actors wield over the policy process, as opposed to external/international actors. It also captures levels of knowledge of REDD+ among the national actors groups. Both the forestry reform of 1994 and the ongoing REDD+ process, were driven by global forces; the 1994 reform had an economic basis and was driven by the World Bank (Tchoungui et al. 1995, Ekoko 1997, Brunner and Ekoko 2000), whereas REDD+ is propelled by concerns about climate change, as expressed in the United Nations Framework Convention on Climate Change (UNFCCC). Although REDD+ was originally seen as a quick, cheap, and easy approach to climate change mitigation (Angelsen and McNeill 2012), internationally driven national forest policy processes tend to encounter massive implementation challenges (Smouts 2001, Howlett and Ramesh 2002). An examination of the role of national ownership in earlier policy reforms, such as Cameroon's 1994 forestry law reform (Ekoko 1997, Brunner and Ekoko 2000, Topa et al. 2009), could therefore provide valuable lessons for the national REDD+ process.

Inclusiveness of policy processes refers to the participation of all stakeholders in decision making, including actors from sectors outside of the forestry sector such as agriculture and mining and state agencies and civil society organizations (CSOs), at not only national but also regional and local levels. An inclusive policy process is more likely to consider equity and is less likely to generate tension and open conflict among policy actors and other stakeholders (Di Gregorio et al. 2012, Peskett and Brockhaus 2009, Thompson et al. 2011).

As Brockhaus and Angelsen (2012) suggest, in addition to the aforementioned preconditions required to achieve transformational change, there are a number of opportunities and challenges related to the four Is that must be carefully negotiated. To bring about transformational change in relation to REDD+, a number of elements must be present, including: new economic incentives and information, and new actors and coalitions that can lead to changes in power relations. Environmental policy domains are shaped by a multitude of actors, who often try to influence the policy process to realize outcomes that relate to their interests. Policy networks, the structures through which actors negotiate and try to influence policy processes, are gaining greater attention from scholars of environmental governance trying to analyze complex environmental policy problems such as climate change mitigation (Bodin and Crona 2009). The use of social network analysis can be a useful tool in revealing potential coalitions between actors in the REDD+ policy arena. These coalitions are defined by the deliberate coordination of actor groups' activities with the aim of influencing policy decisions (Knoke 2011).

In this paper we investigate and assess the role of the above factors in the forest policy reform process of 1994, and how they may have affected its success. We argue that a comparison of these findings, in particular with regard to: autonomy from private sector interests; national ownership over the policy process; inclusiveness; and the influence of various actors within the policy domain of the ongoing REDD+ process, provide useful lessons that may be used to overcome the obstacles that have led to shortcomings in the 1994 reform process.

\section{METHODS}

We drew on both qualitative and quantitative data generated within the global comparative study on REDD+ conducted by the Center for International Forestry Research (Brockhaus and Di Gregorio 2012). We analyzed the politico-economic context in Cameroon (Dkamela 2011, Brockhaus et al. 2012), and examined the network of actors in the REDD+ arena $(F$. Kengoum, M. Brockhaus, M. Di Gregorio, G. P. Dkamela, and J. Schurre, 2012, unpublished manuscript).

The contextual analysis included a literature review, an analysis of policy documents and public statements, participant observation during meetings, and 18 semistructured interviews with key policy actors involved in REDD+ decision making. We sought information on: the political, economic, and institutional constraints and opportunities associated with the adoption of REDD+ policies at the national level; the drivers of deforestation and forest degradation; and proposals for REDD+ policies.

To identify lessons for REDD+ from past efforts in Cameroon, framed around autonomy, national ownership, and inclusiveness, we supplemented these methods with a review of the literature on the 1994 forestry law reform and its outcomes. This literature review combined with semistructured interviews enabled us to investigate the two policy processes.

We employed social network analysis (SNA) to examine actors' networks in the REDD+ policy arena, and to answer questions related to influence, information sharing and coalition building. In particular, we explored the prominence or influence of actors and actor groups, i.e., sets of organizations with similar characteristics, and the interactions and information exchange between them (see Wassermann and Faust 1994, Hanneman and Riddle 2011).

We conducted a policy network survey of policy actors (organizations) from April to November 2011 in the REDD+ policy domain in Cameroon. The focus of the analysis was on actors' centrality, that is, their prominence in the policy network as measured by their visibility to other actors (Knoke and Yang 2008), in two ways: (i) perceived influence and (ii) information exchange. The data were converted and analyzed using UCINET and NetDraw software (Borgatti et al. 1999, Borgatti 2002).

Respondents were identified by an expert panel as relevant in the policy domain, and were representatives of organizations who 
Table 1. In-degrees of each actor group, indicating their perceived influence.

\begin{tabular}{|c|c|c|c|c|}
\hline Actor group & $\begin{array}{l}\text { No. of } \\
\text { members }\end{array}$ & $\begin{array}{l}\text { In-degrees per } \\
\text { group }\end{array}$ & $\begin{array}{c}\text { Cumulative } \\
\text { in-degrees }\end{array}$ & $\begin{array}{c}\text { Cumulative average } \\
\text { in-degrees }\end{array}$ \\
\hline State & 7 & 134 & $\begin{array}{l}\text { National actors: } \\
\quad 343\end{array}$ & National actors: 11.83 \\
\hline National research institutes & 5 & 52 & & \\
\hline Domestic NGOs & 11 & 95 & & \\
\hline Domestic businesses & 6 & 62 & & \\
\hline International NGOs & 12 & 139 & $\begin{array}{c}\text { International/ } \\
\text { foreign actors: } 473\end{array}$ & $\begin{array}{c}\text { International/ } \\
\text { foreign actors: } 14.33\end{array}$ \\
\hline $\begin{array}{l}\text { Intergovernmental organizations and } \\
\text { international research organizations }\end{array}$ & 12 & 235 & & \\
\hline Foreign/multinational businesses & 4 & 32 & & \\
\hline Foreign govt agencies & 5 & 67 & & \\
\hline Others $^{\dagger}$ & 2 & 16 & & \\
\hline
\end{tabular}

$\dagger$ "Others" includes two organizations that do not fall into any of the eight actor groups.

Source: F. Kengoum, M. Brockhaus, M. Di Gregorio, G. P. Dkamela, and J. Schurre, 2012, unpublished manuscript.

also considered themselves to be relevant. Of the 64 actors identified by the expert panel, 42 participated in the survey. Many of those that declined were private sector or state actors and cited lack of time or knowledge as their main reason for not taking part (F. Kengoum, M. Brockhaus, M. Di Gregorio, G. P. Dkamela, and J. Schurre, 2012, unpublished manuscript). The low response rate and only partial participation of actors in the network survey represent a limitation of the study. Significantly, the most influential actor, the Ministry of Environment, Nature Protection, and Sustainable Development (MINEPDED), as determined by responses to the network survey, did decline to participate. This might affect the reliability of the results, particularly because this actor's nominations might change the structure of the information exchange network (Fig. 2). The effect on the reputational influence measure (Fig. 3) is less significant because influence as perceived by other policy actors in the domain (see Table 1 and Fig. 3) is assessed based on in-degree centrality, that is, the number of times an actor is identified as influential by other actors (Freeman 1978-1979, Hanneman and Riddle 2005, Prell 2011). All 64 actors identified are represented in the network of perceived influence, but the network of information exchange comprises only the 42 actors that participated in the survey (F. Kengoum, M. Brockhaus, M. Di Gregorio, G. P. Dkamela, and J. Schurre, 2012, unpublished manuscript). We therefore interpret the results of the information exchange network with caution. We also discuss the role of MINEPDED, even though not directly interviewed, by drawing on the literature review (see Fig. 1).

We measured betweenness centrality for individual organizations in the information exchange networks as an indicator of brokerage (Fig. 2). Betweenness is the number of shortest paths from all nodes (organizations) to all others that pass through one specific node (organization). High betweenness centrality scores indicate that an actor has a favorable position for facilitating and controlling communication flows, where higher scores indicate a position of brokerage (Hannemann and Riddle 2011). Figure 2 displays the information exchange flows for all 42 actors and betweenness scores of actors (size of nodes). We present only reciprocal information exchanges, that is, in which both actors
Fig. 2. Betweenness centrality of information exchange (size of nodes reflects betweenness scores). Source: F. Kengoum, M. Brockhaus, M. Di Gregorio, G. P. Dkamela, and J. Schurre, 2012, unpublished manuscript.
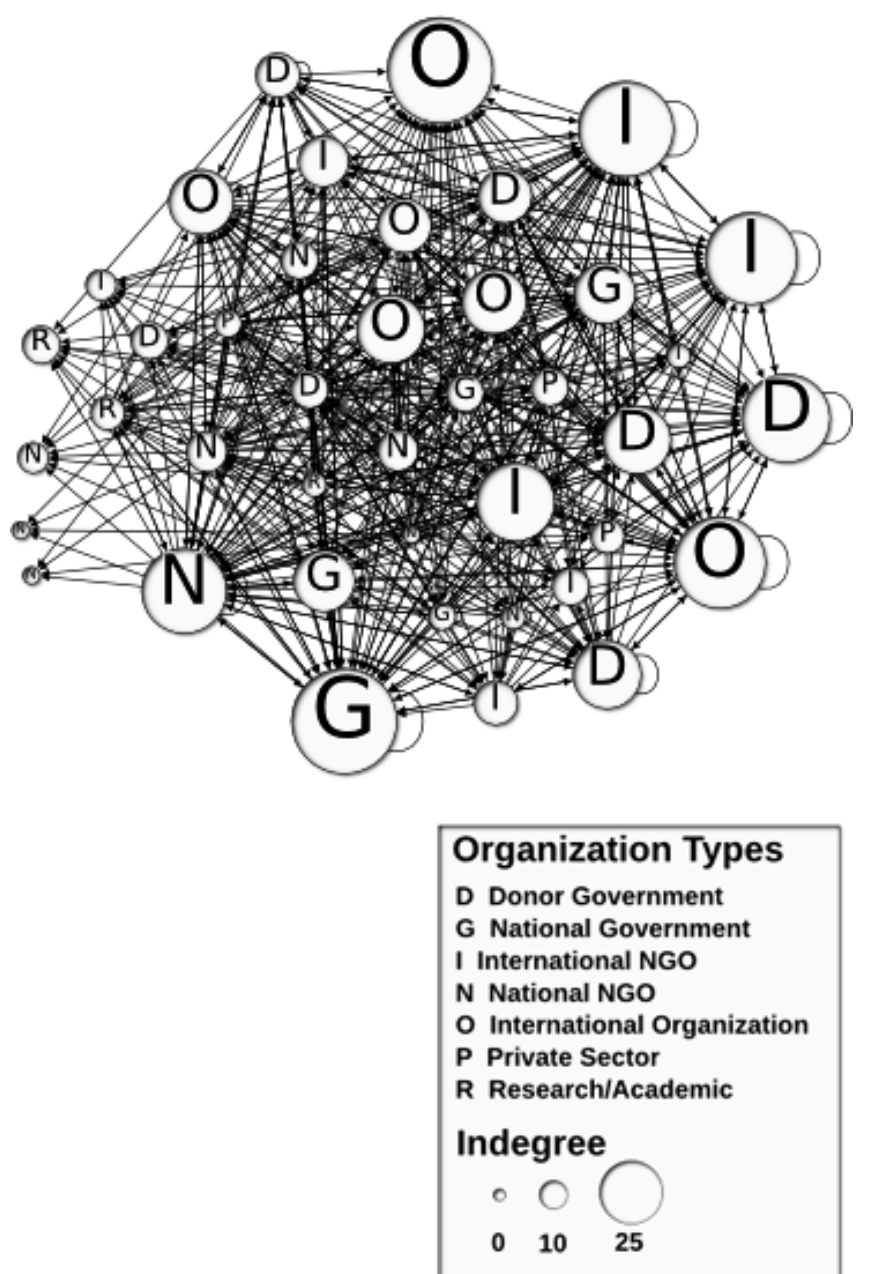
Fig. 3. Relative influence of actors in the REDD+ policy arena in Cameroon. The size of nodes indicates the number of in-degrees (how often members in the actor group were named as influential by interviewees). The thickness of the ties indicates the number of nominations across actor groups (how often members of a group identified members of another group as influential). Self-nomination was excluded. Source: F. Kengoum, M. Brockhaus, M. Di Gregorio, G. P. Dkamela, and J. Schurre, 2012, unpublished manuscript.

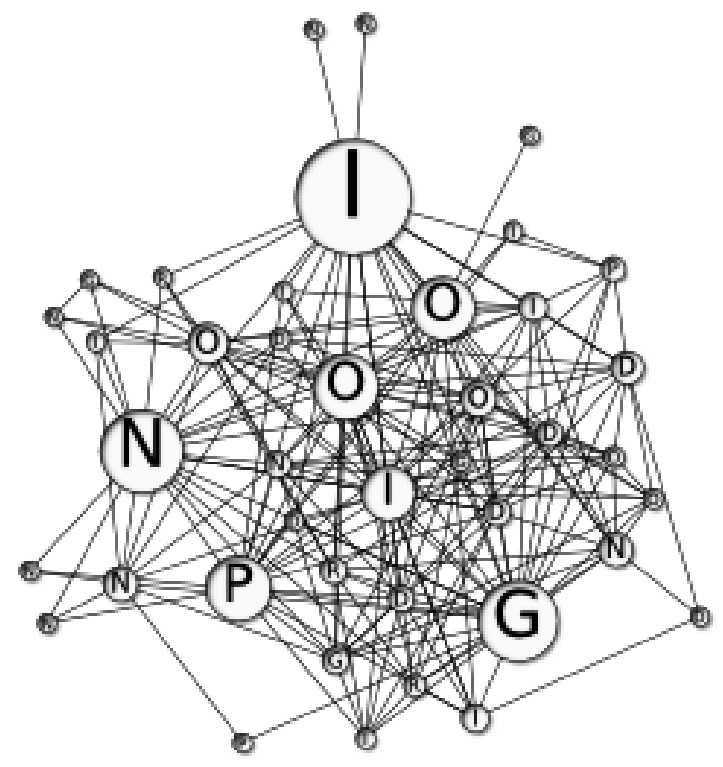

\begin{tabular}{|l|}
\hline Organization Types \\
D Donor Government \\
G National Government \\
I International NGO \\
$\mathrm{N}$ National NGO \\
O International Organization \\
P Private Sector \\
R Research/Academic \\
Normalized \\
BetweennesS \\
$0 \quad 0$ \\
$0 \quad 0.25$ \\
\hline
\end{tabular}

indicated that they had exchanged information with each other. By considering reciprocity, we can identify mutual relationships in which actors from different groups work together and may even build coalitions through information sharing.

\section{RESULTS}

\section{Autonomy, ownership, and inclusiveness in the 1994 forestry law} reform

We assess the 1994 forestry law reform in Cameroon with reference to autonomy, ownership, and inclusiveness, and contend that the reform failed to provide optimal conditions for an effective policy process for several reasons. First, replacing the existing "chaotic and opaque arrangements" for accessing forest resources with a more rational, transparent, equitable, and environmentally sustainable system (Topa et al. 2009:27) proved to be difficult because of the strong influence exerted by private interests during debates on the 1994 forestry law. Many senior officials in the Ministry of Environment and Forestry, as it was named at the time, strongly opposed the reform because they saw some proposals by the World Bank as a threat to their ability to capture benefits through exercising their discretionary powers (Ekoko 1997, Brunner and Ekoko 2000). In parliament, partisan political gains and self-interest were behind the decision to reject the proposed auction system for allocating forest concessions; in fact, many parliamentarians were involved in logging, either directly or indirectly as shareholders in logging companies or as owners of licenses leased to foreign companies (Ekoko 1997, Brunner and Ekoko 2000). The literature on the 1994 law over the course of 20 years reveals weak state autonomy from interests driving forest loss and highlights the prominence of unlawful activities (see Agir Ici and Survie 2000, Nguiffo 2001, 2004, Labrousse and Verschave 2003, Cerutti and Tacconi 2006, Vandenhaute and Doucet 2006, REM 2009, Cerutti and Lescuyer 2011). These findings show how the system of political patronage is intertwined with the forestry sector and how private interests prevail both in decision making and in day-to-day enforcement of regulations. REDD+ will similarly encounter this challenge.

The pressure exerted by foreign logging companies on lawmakers was a second reason for the failure of the 1994 reforms. Many companies sought to consolidate their privileges, which compromised state autonomy. For instance, companies from France, which received more than half of Cameroon's log exports in 1993, lobbied through French officials against a proposed ban on log exports (Ekoko 1997, Brunner and Ekoko 2000). The law originally adopted by parliament stated that $70 \%$ of the total production of logs (of each species) would be processed by local industries during a transitional period (1994-1999), with a full prohibition on the export of logs in force by 1999 (Government of Cameroon 1994). However, following pressure from the logging industry, the government changed this provision shortly before its implementation, by separating tree species into two groups: species prohibited for export and "species in promotion," for which surcharges on log exports would be levied (Government of Cameroon 1999). As a result, the enforcement of the export ban was delayed and the most profitable species were not covered by the ban (Labrousse and Verschave 2003). This reversal benefitted foreign companies. In this instance, France's political support of the Cameroonian government at the time, and their vested interests in the logging sector compromised the state's autonomy with regard to forestry-related matters.

The 1994 forestry law reform process was similarly characterized by lack of government ownership and minimal inclusiveness (Ekoko 1997, Brunner and Ekoko 2000). The World Bank initiated the reforms for economic reasons; in its Structural Adjustment Programme, imposed on Cameroon from 1988, the World Bank used the forestry sector as a guarantee for servicing the debt based on the sector's generation of state revenue (Tchoungui et al. 1995, Ekoko 1997, Brunner and Ekoko 2000). The Ministry of Environment and Forestry, which was established in 1992, at times appeared passive during debates of the law and 
demonstrated weak leadership in involving other ministries and major stakeholders (Ekoko 1997, Brunner and Ekoko 2000). Later, its poor performance in implementing regulations was attributed in part to a shortage of qualified senior staff (MINFOF 2005, 2007; Ministry of Environment and Forestry, unpublished report). Civil society and forest-dwelling communities had little or no involvement in debates on the law (Nguiffo 1994, Ekoko 1997), and, according to Nguinguiri (1999), the law's basis in technical information and foreign ideologies, and its omission of forest-dwelling communities' knowledge and opinions made it highly likely to fail. In many ways, the 1994 law did appear to improve on its predecessor, Law No. 81-13 (Government of Cameroon 1981), in terms of social justice and environmental sustainability because of its inclusion of provisions ostensibly aimed at responding to communities' needs and environmental concerns. However, its practical applications focused heavily on timber production and affirmed the state's desire to retain control over forest resources and associated revenue (Batibonak 2004, Bomba 2004a). Moreover, the literature reveals considerable skepticism regarding whether positive environmental and social outcomes have been achieved, with little evidence of sustainable management (Vandenhaute and Doucet 2006, Cerutti et al. 2008), effective local collective actions, or improvements in communities' livelihoods (Bigombé Logo 2003, Bomba 2004b, Oyono 2004, 2005, Joiris and Bigombé Logo 2008, Bigombé Logo et al. 2010, Mbetoumou et al. 2010, Becker and Tchala 2011).

\section{Brief overview of REDD+ in Cameroon}

To date, Cameroon has made only limited progress in REDD+ decision making (Korhonen-Kurki et al. 2014). In early 2013, the World Bank's Forest Carbon Partnership Facility (FCPF) finally endorsed Cameroon's Readiness Preparation Proposal (R-PP), a five-year process that started with the submission of its Readiness Plan Idea Note (R-PIN) in July 2008 (see Fig. 1). In addition to this, MINEPDED, which represents the country to the UNFCCC, and the Ministry of Forests and Wildlife (MINFOF), which is likely to oversee REDD+ projects, have been in competition over financial resources and leadership since they were created in 2005 after the division of the Ministry for Environment and Forestry (Dkamela 2011). Key events relevant to the national REDD+ policy process from 2005 to 2014 are summarized in Figure 1.

\section{Actors in the REDD+ policy arena}

We identified eight actor groups (Table 1, Fig. 3; F. Kengoum, M. Brockhaus, M. Di Gregorio, G. P. Dkamela, and J. Schurre, 2012, unpublished manuscript), listed in order of their perceived influence in the REDD+ arena and divided into four categories based on their perceived influence: "most prominent" (more than 200 in-degrees): intergovernmental organizations and international research organizations; "prominent" (100-200 in-degrees): international NGOs and state agencies; "less prominent"(50-99 in-degrees): domestic NGOs, foreign government agencies, domestic businesses, and national research institutes; and "least prominent": multinational businesses (fewer than 50 in-degrees).

The fact that survey respondents did not mention any universities, community groups, or local authorities as influential actors in the REDD+ arena indicates the low profile of these groups. However, given that previous studies report the absence of most actors from the policy arena (Dkamela 2011, Kengoum 2011, Somorin et al.
2014), the degree of interest in our survey and the range of actors considered influential indicate that the group of actors involved in REDD+ policy is increasing, not only in number but also in diversity. These dynamics may have implications for inclusiveness and coalition building.

\section{Power and influence in the REDD+ policy arena}

A comparison of national and international actors shows that the latter are more powerful and influential than national actors (average number of in-degrees for all international actors is 14.33, compared with 11.83 for all national actors; Table1). Most of the international actors, with the exception of the private sector, are members of the Consultation Circle of Partners of MINFOF and MINEPDED (CCPM). The CCPM has been active in forestry issues for more than a decade, with monthly meetings held to support the two ministries' activities. CCPM members hold a privileged position in the REDD+ arena because they act as mediators and facilitators among the national actors (see their betweenness centrality in information exchange in Fig. 2). Their dominance is further reflected in media reports on REDD+ (Kengoum 2011). The prominence of international actors in the $\mathrm{REDD}+$ arena reveals that foreign actors continue to dominate national policy processes in Cameroon, as was also seen in the 1994 forestry law reform.

Among national actors, the perceived prominence of state agencies in the REDD+ policy domain is due to the institutional leadership assumed by MINEPDED. MINEPDED is responsible for climate-related policy (Government of Cameroon 2005a) and has represented Cameroon in REDD+ negotiations and R-PP preparations (MINEPDED 2013). The formal functions and roles of MINFOF, the ministry responsible for forests, also influence the perception that it is highly relevant; MINFOF's duties include regeneration, reforestation, forest inventories, and monitoring and application of logging standards (Government of Cameroon $2005 b$ ), which makes this ministry a potential leader on issues such as monitoring, reporting, and verification for REDD + as well as on field projects on conservation concessions.

The low level of influence over REDD+ of state agencies in charge of agriculture, mining, land tenure, and economic planning (Dkamela 2011; F. Kengoum, M. Brockhaus, M. Di Gregorio, G. P. Dkamela, and J. Schurre, 2012, unpublished manuscript) implies a lack of inclusiveness, as does the limited leadership of MINEPDED. In fact, institutionalization of the REDD+ process appears to be weak and slow in Cameroon compared with other countries. For example, Cameroon took 55 months to progress from its R-PIN (July 2008) to its R-PP (January 2013), whereas the Democratic Republic of Congo took 27 months and the Republic of Congo 43 months (http://www.forestcarbonpartnership. org). The poor performance of national REDD+ leadership recalls that of the former Ministry of Environment and Forestry during the 1994 reform.

By contrast, the contribution of national civil society to the REDD+ policy process is evident in its position as the second most influential national actor group and fourth most influential overall (Table 1). In particular, a small number of national NGOs have been carrying out awareness-raising and capacity-building projects. One of the most visible in the arena, the Centre for Environment and Development, launched "Focus on REDD," the first Cameroonian newsletter dedicated to the issue, and 
completed the first field project on community payments for ecosystem services (see Awono et al. 2014). In addition, the REDD+ and Climate Change Platform, made up of almost 60 CSOs, which claim to be assembled in 19 civil society networks (REFACOF, RFC, and ROS4C 2011), was created in July 2011 with the aim of coordinating and channeling members' contributions to REDD+ policy.

\section{Interaction and coalition building in Cameroon's REDD+ policy network}

We describe the main patterns of communication and information flows among the actor groups (see Fig. 2) and the implications of collaboration on information exchange and the formation of coalitions for change. We consider the dynamics between the four actor groups, including: (i) the well-established interactions framework among international actors, (ii) collaboration and conflict between government agencies, (iii) attempts to create a collective movement among CSOs, and (iv) the absence of the private sector.

International NGOs are central to information sharing, and their links with intergovernmental and international research organizations and foreign government agencies (Fig. 2) show that significant interactions occur among international actor groups, which form part of the CCPM. This well-established platform gives the Cameroonian government both technical and financial support through the Forest and Environment Sector Program launched in 2003 (MINEF 2003). Following the rise of REDD+ in the national domain (see Fig. 1), many attempts have been made to create synergies and coordinate activities by CCPM members to build a platform for discussing the direction of REDD+ policy in Cameroon. To this end, a REDD+ subgroup was created in 2011 and, in 2012, the Climate Change Multi-Partners' Platform was introduced, with the broad objective of monitoring climaterelated policy processes and activities. Although the Climate Change Multi-Partners' Platform was created by CCPM members, the intention was to include other organizations as well. Although there is no available registry for CCPM members' REDD+ activities and funding, this information is freely shared. As each member contributes its own funding, there seems to be an informal agreement regarding the tasks that each organization assumes responsibility for, such as policy process facilitation, pilot projects, or monitoring, reporting, and verification. Tools such as the Forest and Environment Sector Program "basket fund," which members raise and manage together, were introduced to avoid competition and duplication. However, most international actors' funding is not channeled through the basket fund, because each organization has its own mission, agenda, and reporting system. The CCPM coalition possesses what other actor groups claim to lack, namely knowledge and funding, which are valuable resources when seeking to influence civil society and governmental agencies.

One state agency, MINFOF, is central in exchanging information on REDD+, but interacts primarily with international actors, with very weak links to other national actor groups (Fig. 2). In addition, MINEPDED, which is not represented in Figure 2 because it did not participate in the survey, is highly likely to be central in the communication network because it is leading the REDD+ process and is perceived by others as the most influential actor (see Fig. 3). The fact that only a few ties between the state agencies (MINFOF, and the Ministry of Finance) appear in Figure 2 suggests poor or nonexistent coordination between them at this stage. Because of the absence of any alliances between government agencies at this stage of the REDD+ process, it appears that the same patterns are being repeated as were observed in 1994, such as weak collaboration and contradictory policy choices. A few domestic NGOs are connected to the international actors that are central to REDD+ information networks, but there is no substantial communication within the CSO actor group (Fig. 2).

Despite the creation of the REDD+ and Climate Change Platform to coordinate the voices and actions of CSOs, limited exchange of information among the CSOs indicates weak collective action within the REDD+ context. The history of the R-PP demonstrates this weakness. The REDD+ and Climate Change Platform, which worked closely with MINEPDED, expressed its support for the approval of Cameroon's R-PP by the FCPF Participants Committee (National REDD+ and Climate Change Platform 2012). However, the Forests and Communities Platform, a CSO platform of about 40 organizations created within the framework of the EU's Forest Law Enforcement, Governance and Trade Voluntary Partnership Agreement (FLEGT-VPA) published requests for further improvements to the R-PP before approval (Forests and Communities Platform $2012 a, 2012 b$ ). The fact that most members of the REDD+ and Climate Change Platform are also members of the Forests and Communities Platform raises questions about the consistency of their discourse. The division within the CSO group, illustrated by such inconsistencies and competition between voices, explains, in part, its difficulty in establishing effective mechanisms for influencing the policy elite.

The private sector is not an apparent participant in Cameroon's REDD+ program, either as single actor or as a group (see Figs. 2 and 3), which could undermine the effectiveness of REDD+. However, the absence of private sector voices could indicate that a strong business-state relationship is active behind the scenes (Newell 2000, Di Gregorio et al. 2012). For example, the recent decision on the allocation of Ngoyla-Mintom forest concessions (see Fig. 1) could be interpreted in this way. Allocation of forest concessions for Ngoyla-Mintom, one of the few remaining intact forest landscapes in Cameroon, was halted in the 1990s because of its high conservation value and pressure from environmentalists. In August 2012, the government allocated six of the nine concessions to logging companies and postponed the attribution of the three remaining concessions (almost 32\% of the surface area); these will likely be allocated to environmental offset and REDD+ projects (MINFOF 2012b). This decision represented an attempt by the Cameroonian government to find a balance between logging and conservation lobbies. However, environmentalists and human rights activists maintain that this approach will support neither environmental protection, nor community rights and livelihoods (Nguiffo 2012). This decision suggests that the private sector can very effectively, albeit often invisibly, influence policy elites within a patronage and rentseeking system, which has implications for any type of benefitsharing system within REDD+ (Assembe-Mvondo et al. 2013). This raises concerns about the viability of attempts to end business as usual and achieve the transformational change required for REDD+ (Di Gregorio et al. 2012). 


\section{DISCUSSION}

\section{Autonomy, the state, and business forces driving deforestation and degradation}

As our results show, connections between politics and business, and the strength of vested private interests have severely limited the autonomy of the state and their ability to make policy decisions that could help curb forest loss. Reports by the Forest Law Enforcement and Governance's independent observer confirmed that political and administrative elites are closely connected to illegal forestry activities (REM 2009, AGRECO $2012 a, 2012 b$ ). The prevalence of corruption and collusion in the forestry sector in Cameroon has made it the "perfect currency for political support" (Vincent et al. 2005, as cited in Topa et al. 2009:18) and the country's "hub of corruption" (Transparency International 2007), which severely constrains law enforcement. By way of explaining the system, Nguiffo (2001) notes that a party can receive benefits from forests either directly, by using a position of power to create logging permits (legal or de facto), or indirectly, by pressuring political or administrative decision makers to make decisions in that party's favor that would not have been made otherwise. Therefore, REDD+ outcomes would strongly depend on efforts devoted to addressing corruption and collusion.

\section{Shifting to a nationally owned REDD+ process}

As in the case of the 1994 forestry law reform, the REDD+ policy process in Cameroon is predominantly led by international actors; the fragmentation in the policy arena of national actors (government, CSOs, private sector) indicates constraints on national appropriation of the process. Funding sources and lack of knowledge contribute to this weak ownership. Outreach and capacity-building activities on REDD+ to date have been instrumental in increasing stakeholders' interest and knowledge (Dkamela et al. 2009, Dkamela 2011, MINEPDED 2013, Awono et al. 2014, Somorin et al. 2014; F. Kengoum, M. Brockhaus, M. Di Gregorio, G. P. Dkamela, and J. Schurre, 2012, unpublished manuscript); however, only international actors can understand the technical discussions, with documented asymmetry in REDD+ knowledge and information among participants (A. M. Tiani, unpublished manuscript). Therefore, boosting national actors' capacity to access and process information is likely to support national ownership of REDD+. However, strengthening technical capacity will require active engagement and information seeking, particularly by state actors, and our results indicate that such actors do not take an active role in seeking information (high out-degree), but rather remain passive, suggesting a lack of interest in REDD+. In such a case "national ownership" becomes merely rhetoric by international actors (Buiter 2007), meanwhile in Cameroon business as usual practices continue, namely between state actors and private sector interests.

The central position of international actors in the REDD+ arena is also related to their possession and control of information, whereas most national actor groups are at the periphery partly because of their limited knowledge of REDD+. Information hereby functions as a currency and a source of power (Brockhaus and Angelsen 2012). Knowledge also provides access to funding, and there are significant opportunities for REDD+ projects, most of which are undertaken by international actors with very few national organizations having managed to secure project funds (Dkamela 2011). This is another key concern for national ownership of the REDD+ process: without networking or access to information, national actors cannot take ownership because they are unable to develop robust proposals and access the necessary funds.

\section{Toward inclusiveness for national actor groups}

Our research reveals both similarities and differences in the participation of actor groups in the REDD+ process and the 1994 reforms. International and foreign actor groups, primarily the World Bank and France, were prominent in the 1990s (Ekoko 1997, Brunner and Ekoko 2000) and this pattern is being repeated with REDD+. Furthermore, domestic actors and forest-dwelling communities continue to be overlooked. However, the participation of national civil society groups has increased because these were almost absent during the 1994 reforms (Ekoko 1997, Brunner and Ekoko 2000). The 1994 reforms took place at the beginning of political liberalization in Cameroon (see Bratton and Van de Walle 1992, Courade and Sindjoun 1996, Sindjoun 1996). One could argue that increasing democratization of Cameroon since the early 1990s has had implications on the prominence of CSOs within the REDD+ context, and more broadly on the growing diversity of actors in the REDD+ arena. This transition represents a greater degree of openness. The prominence of CSOs could also be linked to their connections with international actors and the ability of many NGOs to tap into their networks to obtain REDD+ information and funding. However, the absence of coalitions supporting substantial policy change suggests that the REDD+ policy process will ultimately be ineffective.

The development of the national REDD + architecture indicates that there is a will to address barriers to the participation of some government agencies, as well as barriers to effective government interactions regarding REDD+. The composition of the national REDD+ Steering Committee, the decision-making body for REDD+ in Cameroon established in June 2012, is intended to address these weaknesses, because 14 of the 19 committee members are government representatives (Government of Cameroon 2012). However, the following constraints still prevail. First, MINEPDED's leadership of the process is weak, and does little to motivate other ministries that show little interest in REDD+. Second, there is a need for collegial leadership between MINEPDED and MINFOF, given the potential for their mandates to complement each other, i.e., organizing the wider policy process and overseeing field projects. However, this is currently prevented by: (i) weak collaboration due to conflict and competition caused by their common history (see Fig. 1), and (ii) the uncertainty as to whether MINFOF will be engaged in a way relevant to its competence, because MINEPDED is running the Technical Secretariat for the National REDD+ Steering Committee and MINFOF is just a member. The tension between these two ministries is related to power and vested private interests. Third, with multiple reforms related to REDD+ under debate, each ministry is following its own agenda, with very little harmonization or coherence between sectors. Effective REDD+ process would require these key weaknesses to be addressed.

The government's authority over the REDD+ steering committee raises concerns about the suitability of the system for building consensus with other actor groups and the inclusiveness of decision making. The composition of the committee has been 
criticized by civil society and indigenous groups for failing to be equally representative of all actors: government agencies hold the majority of the positions on the committee (14 out of 19), with one seat each for parliamentarians, mayors, civil society, indigenous groups, and the private sector (Government of Cameroon 2012). This exclusionary approach contradicts the openness of the REDD+ context highlighted above and represents a barrier to obtaining the buy-in of relevant actors for the REDD+ process.

The observed divisions between CSOs shows that Cameroon does not yet have an effective civil society alliance for REDD+, which limits civil society inclusion and hampers their ability to influence state actors. It is unclear from the CSOs' discourse (REFACOF, RFC, and ROS4C 2011, Forests and Communities Platform $2012 a, 2012 b$ ) whether they are divided by real ideological differences because all advocate equity and social justice, improvement of livelihoods, inclusion, and governance. In particular, the recurrence of issues surrounding local and indigenous communities suggests that CSOs are competing with each other to act as intermediaries for Cameroon's forest poor. Although some CSOs have privileged relations with local and indigenous communities, no CSO-community coalition for REDD+ has been established at the national level because of problems with representation, communities' mistrust of outsiders, and communities' belief that CSOs make money in the name of these groups, which is then not necessarily shared with the communities (see Abega 1999, 2008). Improving this relationship would benefit REDD+ because some CSOs have long-standing experience working with communities and can therefore act as brokers and bridges, and share their knowledge of REDD+.

\section{CONCLUSION}

Our exploration of the 1994 forestry law reform and the REDD+ policy process in Cameroon reveals that few lessons from the past have been used to inform the present. The two policy processes share common weaknesses in relation to autonomy, ownership, and inclusiveness.

We reveal a REDD+ arena that is more open and characterized by the presence of a greater number of more diverse actor groups than existed two decades ago during the forestry reform. In spite of this important trend, several patterns from the early forestry reform are being repeated within the REDD+ context. First, power relations among actors show that international actors are more powerful and influential than national actors because they have control of both information and funding and appear to be better structured and organized. Second, state institutions show weak collaboration and leadership in the REDD+ policy process. The performance of the Ministry of Environment in charge of leading the process has shown weak influence and has failed to gain the buy-in of other state agencies, including the ministries of forestry, agriculture, mining, land tenure, and economic planning, whose responsibilities are relevant to REDD+. Third, though national civil society appears more dynamic within a REDD+ context, their connection to state agencies is still weak and less organized, which prevents them from significantly influencing the ongoing policy process. Fourth, there are missing or less visible actors in the REDD+ arena, such as the national private sector, universities, local and indigenous communities and municipalities. There is no evidence that a national coalition that supports REDD+ policy development and implementation has been formed at this stage. State agencies leading the REDD+ process interact primarily with international actors, have few ties to other governmental bodies and have very weak links to other national actor groups. Similarly, CSOs are primarily connected to international actors while there are neither substantial links within the CSO group nor between the CSOs and government agencies. We contend from this setting that the precondition for initiating transformational change in the forestry sector (Di Gregorio et al. 2012) is missing.

Barriers to state autonomy and decision making within the forest sector represent some of the key problem areas that must be addressed if REDD + is to be effective. There is a need for stronger political will, because influential policy makers are often part of the patronage system that prevails in this sector. Analysis of the attitudes of policy elites could provide a better understanding of the dual-discourse they use. During both the 1994 reforms and REDD+ their attitude can perhaps best be described as "ambiguous" (Grainger 2004, Grainger and Konteh 2007). Policy elites draw on concepts featured in international discourse, such as sustainable forest management and avoided deforestation, to formulate official policies that often do not match activities underway. For example, they might propose measures to curb deforestation that do not accord with the drivers, or institute policies and measures that are not supported by any quantitative evidence. This could be described as politics of hiding, or even politics of "lying," as Ramsay and Bartlett (2000) describe it, a tactic employed by politicians to appear to the international community to be engaging in "political actionism." This approach is particularly effective in a context such as Cameroon, where the increased internationalization of the conservation and management of tropical forests (Smouts 2001) is perceived as a threat to national sovereignty and private agendas. If REDD+ policies in Cameroon are to be truly transformational, the forthcoming national strategy must pinpoint and overcome this type of dual-discourse policy process, which reveals that the apparent "national willingness to play" is in fact absent and indicates strong support for business-as-usual structures and practices within state institutions (see Seymour and Angelsen 2009).

Barriers to strong government interactions hamper both national ownership and inclusiveness of the REDD+ policy process. These barriers could be alleviated by means of the following steps. First, increased collaboration between MINEPDED and MINFOF, the two agencies best equipped to manage REDD+ initiatives, is critical for strong and effective institutional leadership. Such an alliance would facilitate negotiations on key REDD+ issues, both among government agencies and between government and other actor groups, and would build consensus. Greater cooperation is necessary to ensure the effectiveness of REDD+ implementation because many sectoral reforms and investments are underway or planned, with implications for the forest sector. The official discourse on REDD+ as a development tool that supports Cameroon in realizing "Vision 2035" (MINEPDED 2013) is yet to be clearly translated and articulated into sectoral policies and investments, and the role of each sector has not been clarified. The content of the national REDD+ strategy now under development will indicate whether, at a conceptual level at least, 
the inconsistencies between sectoral policies and competition over forest resources will be adequately addressed.

Barriers related to national actor groups' inclusiveness deserve particular attention because they also mean constraints to national ownership of the REDD+ process. There is a need to design an institutional architecture for REDD+ that is open and can accommodate a range of actors' interests and voices, so that it can be extended effectively to regional and local levels, where REDD+ activities will actually take place. Similarly, the missing or less visible key actors in the REDD+ arena should be integrated and encouraged to assume their roles. There is little prospect for transformational change if powerful domestic actors such as the private sector have little desire to participate in REDD+. Furthermore, relations within CSOs and between CSOs and communities must also be improved. Improving relationships within civil society would depend on whether CSOs can build greater unity of interests and discourses and organize collective action. They could achieve such unity by developing a common vision and applying guidelines for collaboration. The relationship between CSOs and local and indigenous communities needs to be further strengthened because CSOs, which tend to have sufficient knowledge of REDD+ to engage at a meaningful level, could potentially act as brokers for indigenous communities who have little access to such information. Finally, emphasis should be placed on the consultation and integration of forest-dwelling communities to ensure that REDD+ is effective and equitable (see Dkamela et al. 2009, Brown 2013, Awono et al. 2014). The actions or inaction of such communities have strong implications for REDD+ outcomes. Because forest-dwelling communities are often removed from both the policy arena and the cities where the REDD+ policy process is underway, more effective organizational channels are needed to reach them. Possible strategies to counter this obstacle include holding REDD+ discussions in rural areas, rather than allowing them to be controlled solely by actors in the capital and a limited number of regional centers. Furthermore, local REDD+ information brokers could be posted to villages across regional areas designated for REDD+ activities.

Moving forward, a shift in the current power structure would represent a major step for national actors and their ownership of REDD+. This scenario would see national actors taking control of the process, thereby increasing its likelihood of success.

Responses to this article can be read online at: http://www.ecologyandsociety.org/issues/responses. $\mathrm{php} / 6839$

\section{Acknowledgments:}

This research is part of the Policy Component of the Center for International Forestry Research's (CIFOR) global comparative study on REDD+ (GCS), led by Dr. Maria Brockhaus. The methods applied in this study build on work undertaken in COMPON (Comparing Climate Change Policy Networks), led by Jeffrey Broadbent and financially supported by the National Science Foundation (NSF). Monica Di Gregorio and Maria Brockhaus adapted the COMPON research "Protocol for Policy Network Analysis" for an analysis of REDD+ policy networks. We would like to thank the two anonymous reviewers for their helpful comments, as well as Monica Di Gregorio, Rachel Carmenta, Caleb Gallemore, Imogen Badgery-Parker, Hannah Watson, Bimo Dwisatrio, and Robert Nasi for their invaluable advice on previous drafts and their support. Funding for CIFOR's research was provided by the Norwegian Agency for Development Cooperation, the Australian Agency for International Development, the UK Department for International Development, and the European Commission.

\section{LITERATURE CITED}

Abega, S. C. 1999. Société civile et réduction de la pauvreté. CLE, Yaoundé, Cameroon.

Abega, S. C. 2008. Argent chaud et argent froid dans les associations: les rites de la remise des fonds. Pages 209-222 in D. Arnoldussen, A. Binot, D. V. Joiris, T. Trefon, P. A. Roulet, and P. Assenmaker, editors. Gouvernance et environnement en Afrique central: le modèle participative en question. Musée royal de l'Afrique centrale, Tervuren, Belgium.

Agir Ici and Survie. 2000. Le silence de la forêt: réseaux, mafia et filière bois au Cameroun. Dossiers Noirs No 14. L'Harmattan, Paris, France.

AGRECO. 2012a. Observateur indépendant au contrôle forestier et au suivi des infractions forestières au Cameroun: rapport technique $n^{\circ} 4$ du 1er Juillet au 31 Décembre 2011. AGRECO and EU, Yaoundé, Cameroon. [online] URL: http://www. oicameroun.org/index.php?option $=\mathrm{com}$ docman\&task $=$ doc download $\&$ gid $=98 \&$ Itemid $=36$

AGRECO. 2012b. Observateur indépendant au contrôle forestier et au suivi des infractions forestières au Cameroun: rapport technique $n^{\circ} 5$ du 1er Janvier au 30 Juin 2012. AGRECO and EU, Yaoundé, Cameroon. [online] URL: http://www.oicameroun.org/ index.php?option $=\mathrm{com}$ docman\&task $=\mathrm{doc}$ download $\&$ gid $=11$ 6\&Itemid $=36$

Alence, R. 2004. Political institutions and developmental governance in sub-Saharan Africa. Journal of Modern African Studies 42(2):163-187. http://dx.doi.org/10.1017/S0022278X04000084

Angelsen, A. 2009. Policy options to reduce deforestation. Pages 125-138 in A. Angelsen, M. Brockhaus, M. Kanninen, E. Sills, W. D. Sunderlin, and S. Wertz-Kanounnikoff, editors. Realising REDD+: national strategy and policy options. Center for International Forestry Research, Bogor, Indonesia. [online] URL: http://www.cifor.org/publications/pdf files/Books/BAngelsen0902. pdf

Angelsen, A., and D. McNeill. 2012. The evolution of REDD+. Pages 31-48 in A. Angelsen, M. Brockhaus, W. D. Sunderlin, and L. V. Verchot, editors. Analysing REDD+: challenges and choices. Center for International Forestry Research, Bogor, Indonesia. [online] URL: http://www.cifor.org/publications/pdf files/Books/ BAngelsen 1201.pdf

Assembe-Mvondo, S., M. Brockhaus, and G. Lescuyer. 2013. Assessment of the effectiveness, efficiency and equity of benefit- 
sharing schemes under large-scale agriculture: lessons from land fees in Cameroon. European Journal of Development and Research 25:641-656. http://dx.doi.org/10.1057/ejdr.2013.27

Awono, A., O. A. Somorin, R. Eba'a Atyi, and P. Levang. 2014. Tenure and participation in local REDD+ projects: insights from southern Cameroon. Environmental Science \& Policy 01 (35):76-86. http://dx.doi.org/10.1016/j.envsci.2013.01.017

Bates, R. H. 1981. Markets and states in tropical Africa: the political basis of agricultural policies. University of California Press, Berkeley and Los Angeles, California, USA.

Batibonak, P.-R. 2004. Quelles politiques forestières en Afrique équatoriale? Pages 317-343 in P. Bigombé Logo, editor. Le retournement de l'état forestier: l'endroit et l'envers du processus de gestion forestière au Cameroun. Presses de l'UCAC, Yaoundé, Cameroun.

Becker, P., and S. Tchala. 2011. Etude sur l'utilisation des revenus forestiers dans le cadre du développement local: état des lieux de dix communes forestières au Cameroun. Ministry of Forestry and Wildlife (MINFOF), Ministry of Environment and Nature Protection (MINEP) and Deutsche Gesellschaft für Internationale Zusammenarbeit (GIZ), Yaoundé, Cameroon. [online] URL: http://www.foretcommunale-cameroun.org/download/

Rapportsurutilisationrevenusforestiers.pdf

Bigombé Logo, P. 2003. Decentralized forest revenue and local development in Cameroon: lessons learned from recent experiences and proposal of an enhancement programme for local capacity. Pages 375-380 in Proceedings of the Second International Workshop on Participatory Forestry in Africa. Food and Agriculture Organization, Rome, Italy. [online] URL: ftp://ftp. fao.org/docrep/fao/006/Y4807B/Y4807B13.pdf

Bigombé Logo, P., A. Yamo, and B. Ngonde. 2010. Les forêts communautaires au village. Pages 105-120 in D. V. Joiris and P. Bigombé Logo, editors. La gestion participative des forêts d'Afrique centrale: un modèle a l'épreuve de la réalité. Editions Quae, Versailles, France.

Bodin, Ö. and B. I. Crona. 2009. The role of social networks in natural resource governance: What relational patterns make a difference? Global Environmental Change 19:366-374. http://dx. doi.org/10.1016/j.gloenvcha.2009.05.002

Bomba, C. M. 2004a. Politique forestière et développement local au Cameroun. Pages 213-241 in P. Bigombé Logo, editor. Le retournement de l'état forestier: l'endroit et l'envers du processus de gestion forestière au Cameroun. Presses de l'UCAC, Yaoundé, Cameroon.

Bomba, C. M. 2004b. Législation forestière et protection des droits des populations locales au Cameroun. Pages 243-275 in $\mathrm{P}$. Bigombé Logo, editor. Le retournement de l'état forestier: l'endroit et l'envers du processus de gestion forestière au Cameroun. Presses de l'UCAC, Yaoundé, Cameroon.

Borgatti, S. P. 2002. NetDraw: graph visualization software. Analytic Technologies, Harvard, Massachusetts, USA.

Borgatti, S. P., M. G. Everett, and L. C. Freeman. 1999. UCINET 5 for Windows: software for social network analysis. Analytic Technologies, Natick, Massachusetts, USA.
Bratton, M., and N. Van de Walle. 1992. Popular protest and political reform in Africa. Comparative Politics 24(4):419-442. http://dx.doi.org/10.2307/422153

Brockhaus, M., and A. Angelsen. 2012. Seeing REDD+ through 4Is: a political economy framework. Pages 15-30 in A. Angelsen, M. Brockhaus, W. D. Sunderlin, and L. V. Verchot, editors. Analysing REDD+: challenges and choices. Center for International Forestry Research, Bogor, Indonesia. [online] URL: http://www.cifor.org/publications/pdf files/Books/BAngelsen1201. pdf

Brockhaus, M., and M. Di Gregorio. 2012. A brief overview: component 1 on national REDD+ policies and processes. CIFOR InfoBrief No.13. Center for International Forestry Research, Bogor, Indonesia.

Brockhaus, M., M. Di Gregorio, and S. Wertz-Kanounnikoff. 2012. Guide for country profiles: global comparative study on REDD (GCS-REDD) Component 1 on National REDD+ Policies and Processes. CIFOR, Bogor, Indonesia.

Brown, M. I. 2013. Redeeming REDD: policies, incentives and social feasibility for a voided deforestation. Routledge, London and New York, UK and USA.

Brown, K., and F. Ekoko. 2001. Forest encounters: synergy among agents of forest change in Southern Cameroon. Society and Natural Resources 14(4):269-290. http://dx.doi.org/10.1080/089$\underline{41920151080219}$

Brunner, J., and F. Ekoko. 2000. Cameroon case study. Pages 59-82 in F. J. Seymour and N. Dubash, editors. Right conditions: the World Bank, structural adjustment and forest policy reform. World Resources Institute, Washington, D.C., USA. [online] URL: http://www.wri.org/sites/default/files/pdf/iffeforest.pdf

Buiter, W. H. 2007. "Country ownership": a term whose time has gone. Development in Practice 17(4-5):647-652. http://dx.doi. org/10.1080/09614520701469856

Cerutti, P. O., and G. Lescuyer. 2011. The domestic market for small-scale chainsaw milling in Cameroon. CIFOR Occasional Paper 61. Center for International Forestry Research, Bogor, Indonesia. [online] URL: http://www.cifor.org/publications/ pdf files/OccPapers/OP-61.pdf

Cerutti, P. O., R. Nasi, and L. Tacconi. 2008. Sustainable forest management in Cameroon needs more than approved forest management plans. Ecology and Society13(2): 36. [online] URL: http://www.ecologyandsociety.org/vol13/iss2/art36/

Cerutti, P. O., and L. Tacconi. 2006. Forests, illegality and livelihoods in Cameroon. CIFOR Working Paper 35. Center for International Forestry Research, Bogor, Indonesia. [online] URL: http://www.cifor.org/publications/pdf_files/WPapers/WP-35.pdf http:// dx.doi.org/10.1080/08941920801922042

Courade, G., and L. Sindjoun. 1996. Le Cameroun dans l'entredeux. Politique Africaine 62:3-14. [online] URL: http://www. politique-africaine.com/numeros/pdf/062003.pdf

Di Gregorio, M., M. Brockhaus, T. Cronin, and E. Muharrom. 2012. Politics and power in national REDD+ policy processes. Pages 69-90 inA. Angelsen, M. Brockhaus, W. D. Sunderlin, and L. V. Verchot, editors. Analysing REDD+: challenges and choices. 
Center for International Forestry Research, Bogor, Indonesia. [online] URL: http://www.cifor.org/publications/pdf_files/Books/ BAngelsen 1201.pdf

Dkamela, G. P. 2011. The context of REDD+ in Cameroon: drivers, agents and institutions. CIFOR Occasional Paper 57. Center for International Forestry Research, Bogor, Indonesia. [online] URL: http://www.cifor.org/publications/pdf files/OccPapers/OP-57.pdf

Dkamela, G. P., F. Kabamba Mbambu, K. Austin, S. Minnemeyer, and F. Stolle. 2009. Voices from the Congo Basin: incorporating perspectives of local stakeholders for improved REDD design. WRI Working Paper. World Resources Institute, Washington, D.C., USA. [online] URL: http://www.wri.org/ publication/voices-from-the-congo-basin

Ekoko, F. 1997. The political economy of the 1994 Cameroon Forestry Law. CIFOR Working Paper 4. Center for International Forestry Research, Bogor, Indonesia.

Ernst, C., A. Verhegghen, P. Mayaux, M. Hansen, and P. Defourny.2012. Cartographie du couvert forestier et des changements du couvert forestier en Afrique centrale. Pages 23-42 in C. de Wasseige, P. de Marcken, N. Bayol, F. Hiol Hiol, P. Mayaux, B. Desclée, R. Nasi, A. Billand, P. Defourny, and R. Eba'a, editors. Les forêts du Bassin du Congo: état des forêts 2010. Publications Office of the European Union, Luxembourg. [online] URL: http://www.observatoire-comifac.net/docs/edf2010/ FR/EDF 2010 FR 01.pdf

Essama-Nssah, B., and J. J. Gockowski. 2000. Forest sector development in a difficult political economy: evaluation country case study series. The International Bank for Reconstruction and Development/The World Bank, Washington, D.C., USA. [online] URL: http://go.worldbank.org/K5S7RF2A10

Etoga Eily, F. 1971. Sur les chemins du développement: essai d'histoire des faits économiques du Cameroun. Centre d'édition et de production des manuels et auxiliaires de l'enseignement, Yaoundé, Cameroon.

Forests and Communities Platform. 2012a. Statement of the Forests and Communities Platform and representatives of indigenous communities on the REDD Readiness Preparation Proposal (R-PP) of Cameroon. The Forest Carbon Partnership Facility, World Bank, Washington, D.C., USA. [online] URL: https://www.forestcarbonpartnership.org/sites/forestcarbonpartnership. org/files/Documents/NGO Statement \%20RPP.pdf

Forests and Communities Platform. 2012b. Additional note to the 13 September Statement of the Forests and Communities Platform on the Cameroon R-PP. The Forest Carbon Partnership Facility, World Bank, Washington, D.C., USA. [online] URL: https://www.forestcarbonpartnership.org/sites/forestcarbonpartnership. org/files/Documents/Addendum $\% 20$ to $\% 20$ the $\% 20$ CSO $\% 20$ Statement\%20eng.pdf

Freeman, L. C. 1978-1979. Centrality in social networks conceptual clarification. Social Networks 1(3):215-239. http://dx. doi.org/10.1016/0378-8733(78)90021-7

Government of Cameroon. 1981. Law No. 81-13 of 27 November 1981 to lay down forestry, wildlife and fisheries regulations. Government of Cameroon, Yaoundé, Cameroon.
" Government of Cameroon. 1994. Law No 94-lof 20 January 1994 to lay down forestry, wildlife and fisheries regulations. Government of Cameroon, Yaoundé, Cameroon.

Government of Cameroon. 1999. Decree No 99/781/PM of 13 October 1999 laying down the application procedures for Article 71 (1) of Forest Law No 94/01 of 20 January 1994 governing forests, wildlife and fishing. Government of Cameroon, Yaoundé, Cameroon.

Government of Cameroon. 2005b. Decree No. 2005/099 of 6 April 2005 to organize the Ministry of Forests and Wildlife. Government of Cameroon, Yaoundé, Cameroon.

Government of Cameroon. 2005a. Decree No. 2005/117 of 14 April 2005 to organize the Ministry of Environment and Nature Protection. Government of Cameroon, Yaoundé, Cameroon.

Government of Cameroon. 2012. Order No. 103/CAB/PM of 13 June 2012 pertaining to the creation, organization of and functioning the REDD+ Steering Committee. Government of Cameroon, Yaoundé, Cameroon.

Grainger, A. 2004. Societal change and the control of deforestation in Thailand. International Journal of Sustainable Development and World Ecology 11:364-379. http://dx.doi. org/10.1080/13504500409469840

Grainger, A., and W. Konteh. 2007. Autonomy, ambiguity and symbolism in African politics: the development of forest policy in Sierra Leone. Land Use Policy 24:42-61. http://dx.doi. org/10.1016/j.landusepol.2005.09.001

Greenpeace. 2012. Palm oil's new frontier: how industrial expansion threatens Africa's rainforests. Greenpeace International, Amsterdam, The Netherlands. [online] URL: http://www. greenpeace.org/international/Global/international/publications/ forests/2012/Congo/PalmOilsNewFrontier.pdf

Grindle, M. S., and J. W. Thomas. 1989. Policy makers, policy choices, and policy outcomes: the political economy of reform in developing countries. Policy Sciences 22:213-248. http://dx.doi. org/10.1007/BF00136320

Grindle, M. S., and J. W. Thomas. 1991. Public choices and policy change: the political economy of reform in developing countries. The Johns Hopkins University Press, Baltimore, Maryland, USA.

Hanneman, R. A., and M. Riddle. 2005. Introduction to social network methods. University of California, Riverside, California, USA.

Hanneman, R. A., and M. Riddle. 2011. Concepts and measures for basic network analysis. Pages 340-369 in J. Scottand and P. J. Carrington, editors. The SAGE handbook of social network analysis. Sage, Thousand Oaks, California, USA.

Hédon, L. 1930. Etude sur la forêt et les bois du Cameroun sous mandat français. Librairie Larose, Paris, France.

Hosonuma, N., M. Herold, V. De Sy, R. S. De Fries, M. Brockhaus, L. Verchot, A. Angelsen, and E. Romijn. 2012. An assessment of deforestation and forest degradation drivers in developing countries. Environmental Research Letters 7:044009. [online] URL: http://iopscience.iop.org/1748-9326/7/4/044009 http:// dx.doi.org/10.1088/1748-9326/7/4/044009 
Howlett, M., and M. Ramesh. 2002. The policy effects of internationalization: a subsystem adjustment analysis of policy change. Journal of Comparative Policy Analysis 4:31-50. http://dx. doi.org/10.1080/13876980208412669

Joiris, D. V., and P. Bigombé Logo. 2008. Dynamiques participatives et développement local dans le Bassin congolais: des rendez-vous manqués? Pages 21-37 in D. Arnoldussen, A. Binot, D. V. Joiris, T. Trefon, P. A. Roulet, and P. Assenmaker, editors. Gouvernance et environnement en Afrique central: le modèle participative en question. Musée royal de l'Afrique centrale, Tervuren, Belgium.

Kanninen, M., D. Murdiyarso, F. Seymour, A. Angelsen, S. Wunder, and L. German. 2007. Do trees grow on money? The implications of deforestation research for policies to promote $R E D D$. Forest Perspectives 4. Center for International Forestry Research, Bogor, Indonesia. [online] URL: http://www.cifor.org/ online-library/browse/view-publication/publication/2347.html

Kapoor, I. 2002. Capitalism, culture, agency: dependency versus postcolonial theory. Third World Quarterly 23(4):647-664. http:// dx.doi.org/10.1080/0143659022000005319

Karsenty, A., and S. Ongolo. 2012. Can "fragile states" decide to reduce their deforestation? The inappropriate use of the theory of incentives with respect to the REDD mechanism. Forest Policy and Economics 18:38-45. http://dx.doi.org/10.1016/j.forpol.2011.05.006

Kaufman, D., A. Kraay, and M. Mastruzzi. 2009. Governance matters VIII: aggregate and individual governance indicators 19962008. Policy Research Working Paper 4978. World Bank, Washington, D.C., USA. [online] URL: http://www-wds. worldbank.org/external/default/WDSContentServer/IW3P/ $\underline{\mathrm{IB} / 2009 / 06 / 29 / 00015834920090629095443 / \text { Rendered/PDF/WPS4978. }}$ pdf

Kengoum, D. F. 2011. REDD+ politics in the media: a case study from Cameroon. CIFOR Working Paper 51. Center for International Forestry Research, Bogor, Indonesia. [online] URL: http://www.cifor.org/publications/pdf_files/WPapers/WP51Kengoum. pdf

Knoke, D. 2011. Policy networks. Pages 210-222 in J. Scottand, P. J. Carrington, editors. The SAGE handbook of social network analysis. Sage, Thousand Oaks, California, USA.

Knoke, D., and S. Yang. 2008. Social network analysis. Series on quantitative applications in the social sciences. Second edition. Sage, Thousand Oaks, California, USA.

Korhonen-Kurki, K., J. Sehring, M. Brockhaus, and M. Di Gregorio. 2014. Enabling factors for establishing REDD+ in a context of weak governance: a qualitative comparative analysis. Climate Policy 14:167-186. http://dx.doi.org/10.1080/14693062.$\underline{2014.852022}$

Labrousse, A., and F.-X. Verschave. 2003. Les pillards de la forêt: exploitations criminelles en Afrique. Dossiers Noirs No 17. Agone, Paris, France. [online] URL: http://atheles.org/lyber pdf/ lyber_414.pdf

Levang, P., and R. Nkongho. 2012. Élites et accaparement des terres au Cameroun: l'exemple du palmier à huile. ENJEUX 47/48:67-74.
Mayaux, P., J. F. Pekel, B. Desclée, F. Donnay, A. Lupi, F. Achard, M. Clerici, C. Bodart, A. Brink, R. Nasi, and A. Belward. 2013. State and evolution of the African rainforests between 1990 and 2010. Philosophical Transactions of the Royal Society B: Biological Science 368(1625):20120300. http://dx.doi.org/10.1098/ rstb.2012.0300

Mbetoumou, M., D. V. Joiris, and S. C. Abega. 2010. La gestion élitiste de la redevance forestière communautaire. Pages 57-83 in D. V. Joiris and P. Bigombé Logo, editors. La gestion participative des forêts d'Afrique centrale: un modèle a l'épreuve de la réalité. Editions Quae, Versailles, France.

Mertens, B., and E. F. Lambin. 2000. Land-cover-change trajectories in Southern Cameroon. Annals of the Association of the American Geographers 90(3):467-494. http://dx.doi. org/10.1111/0004-5608.00205

Mertens, B., W. D. Sunderlin, O. Ndoye, and E. F. Lambin. 2000. Impact of macroeconomic change on deforestation in South Cameroon: integration of a household survey and remotelysensed data. World Development 28(6):983-999. http://dx.doi. org/10.1016/S0305-750X(00)00007-3

Ministry of Environment and Forestry (MINEF). 2003. Programme sectoriel forêts et environnement (PSFE): document de programme. Ministry of Environment and Forestry, Yaoundé, Cameroon. [online] URL: http://www.minep.gov.cm/index.php? option $=$ com content $\&$ view $=$ category $\& i d=37$ :psfe \&layout $=$ blog! Itemid $=3 \&$ lang $=\mathrm{fr}$

Ministry of Environment, Protection of Nature and Sustainable Development (MINEPDED). 2013. Readiness Preparation Proposal (R-PP). Country: Cameroon. Forest Carbon Partnership Facility, World Bank, Washington, D.C., USA. [online] URL: https://www.forestcarbonpartnership.org/sites/ forestcarbonpartnership.org/files/Documents/PDF/Feb2013/Cameroon $\%$ 20final $\%$ 20R-PP-English-January $\% 202013$.pdf

Ministry of Forestry and Wildlife (MINFOF). 2005. Communiqué final. Séminaire sur les dix années de gestion forestière et faunique au Cameroun (1995-2005). MINFOF, Yaoundé, Cameroon.

Ministry of Forestry and Wildlife (MINFOF). 2007. Aidemémoire de la mission conjointe de suivi du Programme sectoriel forets et environnement ( PSFE). MINFOF, Yaoundé, Cameroon.

Ministry of Forestry and Wildlife (MINFOF). 2012a. Appel d'offres national restreint No 0022/AONR /MINFOF/CPM/ FCPSFE/2012 du 18 juin 2012 pour la révision de la Loi No 94/01 du 20 janvier 1994 portant régime des forêts, de la faune et de la pêche, et de ses textes d'application. MINFOF, Yaoundé, Cameroon.

Ministry of Forestry and Wildlife (MINFOF). $2012 b$. Communiqué $N^{\circ} 0214 / C / M I N F O F / S G / D F / S D A F F / S A G d u 28$ aout 2012 portant publication des résultats de l'appel d'offres $N^{\circ}$ 0150/AAO/MINFOF/SG/DF/ SDAFF/SDIAF du 30 mai 2012. MINFOF, Yaoundé, Cameroon.

National REDD+ and Climate Change Platform. 2012. Communiqué: la société civile soutient le R-PP du gouvernement Camerounais. Cameroon Tribune, 24 September. 
Ndoye, O., and D. Kaimowitz. 2000. Macro-economics, markets and the humid forests of Cameroon, 1967-1997. Journal of Modern African Studies 38(2):225-253. http://dx.doi.org/10.1017/ S0022278X00003347

Newell, P. 2000. Climate for change: non-state actors and the global politics of the green house. Cambridge University Press, Cambridge, UK. http://dx.doi.org/10.1017/CBO9780511529436

Nguiffo, S. A. 1994. La nouvelle législation forestière au Cameroun. La Fondation Friedrich-Ebert, Yaoundé, Cameroon.

Nguiffo, S. 2001. Propos sur la gestion neopatrimoniale du secteur forestier au Cameroun. Page 14 in Forest Monitor, editor. La foret prise en otage: la nécessité de contrôler les sociétés forestières transnationale: une étude européenne. Forest Monitor, Cambridge, UK. [online] URL: http://www.forestsmonitor.org/ uploads/2e90368e95c9fb4f82d3d562fea6ed8d/la foret prise en otage. pdf

Nguiffo, S. 2004. La réforme de la législation forestière a-t-elle amélioré la transparence? Terroirs 1-2:191-202.

Nguiffo, S. 2012. Le Cameroun doit opter pour les concessions de conservation. Mutations, 21 August.

Nguiffo, S., and B. Schwartz. 2012. Herakles' 13th labour? A study of SGSOC's land concession in south-west Cameroon. Centre pour l'Environnement et le Développement, Yaounde, Cameroon. [online] URL: http://www.rightsandresources.org/documents/ files/doc 4763.pdf

Nguinguiri, J. C. 1999. De l'usage de l'information a l'appui aux politiques de gestion des ressources naturelles: le cas du Cameroun. Centre Technique de Coopération Agricole et Rurale, Yaoundé, Cameroon. [online] URL: http://internships.cta.int/pubs/ wd8017/wd8017.pdf

Oyono, P. R. 2004. The social and organisational roots of ecological uncertainties in Cameroon's forest management and decentralisation model. European Journal of Development Research 16(1):174-191. http://dx.doi.org/10.1080/09578810410001688798

Oyono, P. R. 2005. Profiling local-level outcomes of environmental decentralization: the case of Cameroon's forests in the Congo Basin. Journal of Environment \& Development 14 (2):1-21.

Peskett, L., and M. Brockhaus. 2009. When REDD+ goes national: a review of realities, opportunities and challenges. Pages 25-43. in A. Angelsen, M. Brockhaus, M. Kanninen, E. Sills, W. D. Sunderlin, and S. Wertz-Kanounnikoff, editors. Realising REDD+: national strategy and policy options. Center for International Forestry Research, Bogor, Indonesia. [online] URL: http://www.cifor.org/publications/pdf_files/Books/BAngelsen0902. pdf

Prell, C. 2011. Social network analysis: history, theory, and methodology. Sage, Thousand Oaks, California, USA.

Ramsay, M., and D. Bartlett, editors. 2000. The politics of lying: implications for democracy. Macmillan, London, UK.

Réseau des femmes africaines pour la gestion communautaire des forêts, Réseau de Foresterie Communautaire, and Réseau des Organisations de la Société civile camerounaise sur les changements climatiques (REFACOF, RFC, and ROS4C). 2011. Communiqué final de la Plateforme nationale REDD et changement climatique. Yaoundé, Cameroon.

Resource Extraction Monitoring (REM). 2009. Evolution $d u$ contrôle et des sanctions de l'exploitation forestière illégale au Cameroun. Resource Extraction Monitoring, Cambridge, UK. [online] URL: http://www.observation-cameroun.info/documents/ REM IMFLEG Cameroun Rapport finprojet.pdf

Rudel, T. K. 2013. The national determinants of deforestation in sub-Saharan Africa. Philosophical Transactions of the Royal Society B: Biological Sciences 368(1625):20120405. http://dx.doi. org/10.1098/rstb.2012.0405

Seymour, F., and A. Angelsen. 2009. REDD wine in old wineskins. Pages 293-303 in A. Angelsen, M. Brockhaus, M. Kanninen, E. Sills, W. D. Sunderlin, and S. Wertz-Kanounnikoff, editors. Realising REDD+: national strategy and policy options. Center for International Forestry Research, Bogor, Indonesia. [online] URL: http://www.cifor.org/publications/pdf files/Books/BAngelsen0902. pdf

Sindjoun, L. 1996. Le champ social camerounais: désordre inventif, mythes simplificateurs et stabilité hégémonique de l'État. Politique Africaine 62:57-67. [online] URL: http://www.politiqueafricaine.com/numeros/pdf/062057.pdf

Smouts, M.-C. 2001. Forêts tropicales, jungle internationale. Le revers de l'écopolitique mondiale. Presses de Sciences Po, Paris, France.

Somorin, O. A., I. J. Visseren-Hamakers, B. Arts, D. J. Sonwa, and A.-M. Tiani. 2013. REDD+ policy strategy in Cameroon: actors, institutions and governance. Environmental Science \& Policy 35:87-97. http://dx.doi.org/10.1016/j.envsci.2013.02.004

Sunderlin, W. D., O. Ndoye, H. Bikié, N. Laporte, B. Mertens, and J. Pokam. 2000. Economic crisis, small-scale agriculture, and forest cover change in Southern Cameroon. Environmental Conservation 27(3):284-290. http://dx.doi.org/10.1017/S0376892900000321

Tanner, T., and J. Allouche. 2011. Towards a new political economy of climate change and development. IDS Bulletin 42 (3):1-14. http://dx.doi.org/10.1111/j.1759-5436.2011.00217.x

Tchoungui, R., S. Gartlan, J. Mope Simo, F. Sikod, A. Youmbi, M. Ndjatsana, and J. Winpenny. 1995. Structural adjustment and sustainable development in Cameroon. ODI Working Paper 83. Overseas Development Institute, London, UK. [online] URL: http://www.odi.org.uk/sites/odi.org.uk/files/odi-assets/publicationsopinion-files/7002.pdf

The Rainforest Foundation UK. 2013. Seeds of destruction: expansion of industrial oil palm: potential impact on forest and people. The Rainforest Foundation UK, London, UK. [online] URL: http://www.rainforestfoundationuk.org/files/Seeds $\% 20$ of $\%$ 20Destruction, \%20February $\% 202013$.pdf

Thompson, M. C., M. Baruah, and E. R. Carr. 2011. Seeing REDD+ as a project of environmental governance. Environmental Science \& Policy 14:100-110. http://dx.doi. org/10.1016/j.envsci.2010.11.006

Topa, G., C. Megevand, A. Karsenty, and L. Debroux. 2009. The rainforests of Cameroon: experience and evidence from a decade of 
reform. World Bank, Washington, D.C., USA. http://dx.doi. org/10.1596/978-0-8213-7878-6

Transparency International. 2007. Cameroon 2007: national integrity systems country study report. Transparency International, Berlin, Germany.

United National Framework Convention on Climate Change (UNFCCC). 2011. Decision 1/CP: the Cancun Agreements: outcome of the work of the ad hoc working group on Long-term Cooperative Action under the Convention. UNFCCC, Cancun, Mexico. [online] URL: http://unfccc.int/resource/docs/2010/ cop16/eng/07a01.pdf

Van de Walle, N. 1989. Rice politics in Cameroon: state commitment, capability, and urban bias. Journal of Modern African Studies 27(4):579-599. http://dx.doi.org/10.1017/ $\underline{\mathrm{S} 0022278 \mathrm{X} 00020450}$

Van de Walle, N. 2001. African economies and the politics of permanent crisis, 1979-1999. Cambridge University Press, New York, New York, USA. http://dx.doi.org/10.1017/CBO9780511800344

Vandenhaute, M., and J. L. Doucet. 2006. Étude comparative de vingt plans d'aménagement approuvés au Cameroun. German Technical Cooperation, Yaoundé, Cameroon.

Wassermann, S., and K. Faust.1994. Social network analysis: methods and applications. Cambridge University Press, New York, New York, USA. http://dx.doi.org/10.1017/CBO9780511815478 